UDC 008+004.946

\section{Цитування:}

Трач Ю. В. Комп’ютерні ігри як складова культури та предмет культурологічного дослідження. Вісник Національної академії керівних кадрів культури $і$ мистецттв : наук. журнал. 2021. № 2. С. 61-64.

Trach Yu. (2021). Computer games as a component of culture and a subject of cultural research. National Academy of Culture and Arts Management Herald: Science journal, 2, 61-64. [in Ukrainian].

\author{
Trach Yuliia, \\ Candidate of Pedagogical Sciences, Professor, \\ Kyiv National University of Culture and Arts \\ ORCID: https://orcid.org/0000-0003-2963-0500 \\ 0411@ukr.net
}

\title{
COMPUTER GAMES AS A COMPONENT OF CULTURE AND A SUBJECT OF CULTURAL RESEARCH
}

The purpose of the article is to characterize computer games as a component of culture and a subject of cultural research. The methodology involves distraction from the technological aspects of the genesis and implementation of computer games and is determined mainly by the humanitarian guidelines for the phenomenon under study. Thus, the methodological principles are based on the cultural research concept of computer games as a value of modern culture. The scientific novelty is that for the first time in Ukrainian cultural research the need to study computer games as a component of culture is actualized. Conclusions. The article highlights the need for cultural research of computer games as a full and equal component of culture. Attention is paid to the scale of the computer games spread, their importance for culture and the individual, as well as the impact on various spheres of human life. Conclusions. It is emphasized that the issue of the creation and functioning of computer games in modern society is an inexhaustible source for further research, including in cultural research. Computer games are a wide "field" for the application of the latest IT developments, philosophical ideas, and artistic innovations. Therefore, this issue will remain in the focus of research not only for cultural scientists but also for philosophers, educators and psychologists, sociologists, economists, and jurists, given the pace and scale of the information spread and communication technologies, and most importantly their complexity.

Key words: computer games, information technology, culture, art.

Трач Юлія Василівна, кандидат педагогічних наук, професор Київського національного університету культури і мистеитв

Комп'ютерні ігри як складова культури та предмет культурологічного дослідження

Мета статті - охарактеризувати комп'ютерні ігри як складову культури та предмет культурологічного дослідження. Методологія дослідження передбачає відволікання від технологічних аспектів генезису i реалізації комп'ютерних ігор, і визначається переважно гуманітарними настановами на досліджуваний феномен. Відтак, методологічні засади грунтуються на культурологічній концепції комп'ютерної гри як цінності сучасної культури. Наукова новизна полягає в тому, що вперше в українській культурології актуалізовано потребу вивчення комп'ютерних ігор як складової культури. Результати. У статті актуалізовано потребу культурологічного дослідження комп'ютерних ігор як повноцінної і рівноправної складової культури. Звернено увагу на масштаби розповсюдження комп'ютерних ігор, їх значення для культури та окремого індивіда, а також вплив на різні сфери життєдіяльності людини. Висновки. Наголошено, що проблематика створення і функціонування комп’ютерних ігор в сучасному суспільстві - невичерпне джерело для подальших досліджень, зокрема й у культурології. Комп’ютерні ігри - це широке поле для застосування новітніх ITрозробок, філософських ідей і мистецьких нововведень. Відтак, ця проблематика ще довго перебуватиме у фокусі досліджень не лише культурологів, а й філософів, педагогів і психологів, соціологів, економістів i правознавців, зважаючи на темпи і масштаби розповсюдження інформаційно-комунікаційних технологій, а головно - їх складність.

Ключові слова: комп’ютерні ігри, інформаційні технології, культура, мистецтво.

Introduction. Computer games have long been part of popular culture, along with cinema and pop music, and a system of mass cultural production (creative industries), which has 
original aesthetic properties. In developed countries, computer games are even recognized as art (in France is since 2006; in Germany is since 2008, in the United States is since 2011), in Korea in general the pride and property of the state and the best gamers there are well known as pop stars. Today, computer games are as popular as literature and cinema and affect culture no less, not to mention profits where the global film industry earns billions of dollars less than the gaming industry (according to the authoritative gaming market think tank Newzoo, in 2020, the profit of the gaming industry amounted to 159.3 billion dollars [7], while the total profit of the film [3] and music [6] industry is only 62 billion dollars). Just like cinema, computer games are a means of entertainment and a source of aesthetic experiences, just as cinema, computer games are the language in which society discusses problems, and is a source of identities as in cinema, video games offer exemplary types (cool guy, rebel, mercenary, etc.).

Of course, computer games cannot be attributed to the elite or folk culture, but they are a factor in the socialization and organization of everyday life in modern society. For a large proportion of the world's population, they have become an everyday reality, but still, the attitude of society to them remains ambiguous.

Review of recent publications and research. In Ukraine, the study of computer games in modern humanities and social sciences, including cultural studies a relatively new direction. Only some researchers turn to this issue, and even in the context of other issues, for example, in the study of aesthetic features of video games (N. Marenych), the peculiarities of the existence of myth in cyberspace (G. Starkova), and others. Compared to other disciplines, computer games in Ukraine have been most extensively studied in terms of psychology (O. Girchenko and others), pedagogy (O. Androschuk and others), and social communications (O. Sotnikova and others), but these are a few publications. The representatives' works of these sciences are mostly not a specific analysis of a certain aspect of the computer games functioning, but a retelling of already known truths or facts with appropriate citation or insufficiently substantiated and convincing argumentation about the advantages and disadvantages of using computer games. This situation, however, is partly due to the fact that the researcher (especially the humanities or social sciences) is required not only to understand the terminology of information and communication technologies, but also to know clearly their capabilities, the specifics of functioning, and use in various spheres of life, the peculiarities of interaction and influence, development trends, and most importantly to have experience with these technologies, in this case, to be familiar with computer games. In this regard, Dan Pinchbeck, one of the authoritative developers and theorists of video games, said quite emphatically: if a researcher wants to understand video games, he must be able to either write code or develop game concepts.

The purpose of the article is to characterize computer games as a component of culture and a subject of culturological research.

Presenting main material. Over the past two decades, foreign scientists have been actively studying computer games: this research area has been called game studies. The most famous and large centers for the study of computer games are located in Europe. Among them is the Center for Computer Games Research at the University of Copenhagen Information Technology, as well as the Digital Games Research Association (DiGRA) is the Association for Digital Game Research, which has been operating since 2003 in Finland. Many institutes and universities in the United States study computer games, in particular, game design issues, are Forbes singles out more than 20 "best" [1]. Among them: Stanford University, which annually holds Interactive Media \& Games seminars, inviting scientists, industry, and players, as well as New York University, which studies game design, development, game journalism, and game studies. Employees of these scientific and educational institutions (Espen Aarseth, Ian Bogost, Chris Crawford, Frans Mäyrä, etc.) conduct specialized research, organize numerous conferences, symposia, festivals, and publish their work in specialized scientific journals, such as Game Studies. The International Journal of Computer Game Research [4], the main topics of which are aesthetic, cultural, and communicative aspects of games. DiGRA publishes the journal Transactions of the Digital Games Research Association [10], which publishes research on computer games in the fields of sociology, design, anthropology, psychology, and programming. The Games and Culture magazine [5] by SAGE Publications is dedicated to the socio-cultural, political, and economic dimensions of gaming. Springer publishes The Computer Games Journal, [8] which covers programming in particular programming questions; gaming habits of gamers; copyright; moral and legal consequences associated with gaming content. Elsevier, one of the world's largest publishing houses, publishes Entertainment Computing [2], dedicated not only to video games but also to digital entertainment in 
general, in particular social networks, which have recently become a "platform" for computer games.

Therefore, computer games as a full-fledged component of modern culture should be the object of cultural research in Ukraine, the main focus of which should be on their socio-cultural effects, opportunities, and trends in their application directly in the field of culture. In addition, we should not forget that computer games are an entertainment business in their technological form, so the study of this aspect is also one of the promising areas of their study. Each such work will become a "brick" in expanding the scientific understanding of the specifics of the interaction of information and communication technologies, including computer games, and culture.

A promising area of study is the history and presence of computer games in Ukraine. This topic is almost unexplored, despite the fact that Ukrainian developments are worth considering at least in terms of their impact on Ukrainian society in the context of information security and information impact (e.g. Combat Mission: the Black Sea, Call of Duty: Modern Warfare, etc.). At the time, the Ukrainian S.T.A.L.K.E.R. game was extremely popular, in which events unfold in the Chernobyl nuclear power plant, and which is based on the novel "Roadside Picnic" Strugatsky brothers and shot on its motives, film director Andrei Tarkovsky's "Stalker". This is an unnecessary reminder that computer games adopt images and artistic techniques from literature and cinema, offering their own characters. The film industry, in turn, borrows images and plots from computer games. Among the best films based on the cult video games are "Lara Croft: Tomb Raider" (2001, by the way, the scenery in the film exactly repeats the atmosphere of the original series of games), "Far Land" (2008), "Prince of Persia: Sands of Time" (2010), "Warcraft" (2016) and others.

One of the messages of leading foreign researchers in computer games is the belief that culture must cooperate with the gaming industry primarily in order to survive. It is not only that such interaction can contribute to the creation of new art forms that will ensure a high level of participation and progressiveness, but also that culture can borrow from this kind of game approaches and vocabulary. Thus, despite the ambiguous attitude of theorists and society in general to computer games, they are an important part of modern culture. This new art form is the product of almost all previous forms of media, and it is reflected in almost all spheres of human life. Computer games today are not just fun. As computer simulators, or simulators (implemented, in fact, on the principle of computer games), they are actively used in the educational process - in special training, the content of which is associated with the development of confident and accurate professional competencies in the classroom, as well as in science-intensive professions, which use complex technologies and technical means. Computer games have become a tool for advancing science: for example, according to the journal "Nature Structural \& Molecular Biology", gamers in a specially created computer game "Foldit" deciphered the structure of the virus-like enzyme AIDS - that is, performed the task, a reliable solution which is absent in modern biology. Today, computer games have become a new form of rhetoric - the so-called procedural rhetoric, the essence of which, according to I. Bogost, is the art of persuasion through the rules of interaction. One of the clearest examples is the computer game "September 12", dedicated to the criticism of the fight against terrorism, or the game McDonald's Videogame as a critique and parody of McDonald's activities.

In the field of culture, video games are used not only as a museum exhibit but also as a tool for disseminating information about cultural artifacts. Yes, foreign museums use video games as a way to attract audiences: the British Museum in London has a flash game Time Explorer, which allows you to view the archaeological finds [9]. In the New York Museum of Modern Art, video games have become full-fledged museum exhibits, where a permanent exhibition of specially selected video game curators has been opened [11].

For a form that is so ubiquitous, progressive, and so popular (and the number of gamers around the world today reaches 2.7 billion [7]), it seems unusual that we still have to argue in favor of computer games as a key part of modern culture. But it is so. Especially in Ukraine, where it is not that there are no special research centers, and research on this issue is carried out very slowly and carefully. Moreover, computer games have long been a "hero of history" that when a new media or a new art form (in this case, it's the same thing), society believes that there is a treasurywhat and what and this must be addressed urgently. Today, computer games are a kind of art, born of the digital age, which requires a change in stereotypes of perception, the rejection of dogmas in society, including science. The computer games study within different sciences is an urgent requirement of the time, given that this type of game has long been an everyday reality, 
and the attitude of society, including cultural scientists, to it has not yet been formed.

Conclusion. Thus, the issue of creation and computer game operation in modern society is an inexhaustible source for further research, and not only within the cultural study. Computer games are a wide "field" for the application of the latest IT developments, philosophical ideas, and artistic innovations. Therefore, this issue will remain in the focus of research not only for cultural scientists but also for philosophers, educators and psychologists, sociologists, economists, and jurists, given the pace and scale of the information spread and communication technologies, and most importantly their complexity.

\section{References}

1. Adams S. (2015). The Top Colleges and Grad Schools To Study Game Design. URL: https://www.forbes.com/sites/susanadams/2015/03/25/t he-top-colleges-and-grad-schools-to-study-gamedesign/?sh=5c1bd3d5541f [application date: 11.10.2020] [in English].

2. Entertainment Computing [official site]. URL :

https://www.journals.elsevier.com/entertainmentcomputing [application date: 19.10.2020] [in English].

3. Film Industry - statistics \& facts. (2020). URL : $\quad$ https://www.statista.com/topics/964/film/ [application date: 19.10.2020] [in English].

4. Game Studies. The International Journal of Computer Game Research [official site]. URL: http://gamestudies.org/0902 [application date: 011.11.2020] [in English].

5. Games and Culture [official site]. URL: https://journals.sagepub.com/home/gac [application date: 11.10.2020] [in English].

6. IFPI Global Music Report 2020: Music Revenues Rise For Fifth Straight Year to \$20 Billion. (2020).

URL : https://www.billboard.com/articles/business/9370682/if pi-global-report-2020-music-sales-paid-streamingcoronavirus-impact [application date: 05.12.2020] [in English].

7. Newzoo Global Esports Market Report 2020. Light Version. (2020). URL : https://newzoo.com/insights/trend-reports/newzooglobal-esports-market-report-2020-light-version/ [application date: 20.01.2021] [in English].

8. The Computer Games Journal [official site]. URL : $\quad$ https://www.springer.com/journal/40869 [application date: 15.12.2020] [in English].

9. Time Explorer - My Poor Brain [official site]. URL :

http://www.mypoorbrain.com/project/timeexplorer/ [application date: 11.10.2020] [in English].

10. Transactions of the Digital Games Research Association [official site]. URL : http://todigra.org/index.php/todigra [application date: 15.12.2020] [in English].

11. MoMA [official site]. URL : www.moma.org [application date: 20.01.2021] [in English].

Стаття надійшла до редакиії 08.02.2021 Отримано після доопраиювання 01.03.2021 Прийнято до друку 05.03.2021 